\title{
The Urgency of Ratification of the 2010 Beijing Convention Concerning Enforcement of Unlawful Acts against International Civil Aviation
}

\author{
Adya Paramita Prabandari \\ Peni Susetyorini \\ Darminto Hartono \\ International Law Department, Faculty of Law, \\ Diponegoro University, Indonesia
}

Doi: 10.36941/ajis-2020-0o2o

\section{Abstract}

Aviation is a mass transportation mode that is transnational (across national borders) that has a high level of security and safety. However, the phenomenon of unlawful acts in international civil aviation is a factor that greatly disrupts the security and safety of aviation. As a member of ICAO, Indonesia is responsible for continuing to keep up of developments in international civil aviation arrangements and making them part of national law, which is of course adapted to national interests. However, until now Indonesia has not ratified the 2010 Beijing Convention. The problem that will be discussed in this study is the urgency of the ratification of the 2010 Beijing Convention on the Suppression of Unlawful Acts relating to International Civil Aviation in Indonesia. This research is normative juridical research that uses secondary data as research material. The results show that as an ICAO member state, Indonesia is urged to immediately ratify the 2010 Beijing Convention as a means of providing legal protection, both preventive and repressive. The ratification is also to enforce laws as a manifestation of Indonesia characterization as a state of law.

Keywords: ratification, Beijing Convention 2010, unlawful acts, international civil aviation

\section{Introduction}

The global order has changed very rapidly since the Three-T Revolution (Transportation, Telecommunications and Tourism). This is reinforced by Dorodjatun Kuntjoro Jakti, as quoted by Riant Nugroho Dwidjowijoto and Marco P. Sumampouw in Globalization, Threats or Opportunities (1997). The Three-T Revolution has been running since the beginning of the 21st century, and is known as globalization. One result of globalization is the development of transportation technology that is very rapid and has given birth to the era of the end of geography (Sitabuana, 2001; Chareonwongsak, 2002), because it causes this world to become borderless (Quebral, 2006). The flow of movement/traffic of people and goods between countries and between regions in various parts of the world that is increasingly fast and as if without limits requires a mode of transportation that is fast, safe, and comfortable, namely by air transportation using airplanes.

On the other hand, related to the security and safety criteria required for transportation using airplanes, the phenomenon of unlawful acts related to international civil aviation (hereinafter referred to as unlawful acts in international civil aviation) is a factor that greatly interferes with 
security and safety the flight. This unlawful act has been a broad discussion of various civil aviation security perspectives since the 1970 with the The Hague Convention of 1970 and The Montreal Convention of 1971 (Agrawala, 1973; Thomas \& Kirby, 1973; FitzGerald, 1974).

Unlawful interference against international civil aviation are "acts or experiments that endanger the safety of aviation and air transport", which include, among others, controlling aircraft in an unlawful manner, carrying out aircraft destruction/destruction on land (in service), taking people hostage in an airplane or at the airport, getting into an airplane or aeronautical places by force, and carrying weapons or equipment that could endanger flight safety (Abeyratne, 2018; Abeyratne, 2019). Even providing false information that could endanger aircraft safety in flight is also included in the category of unlawful acts in civil aviation (The Ministry of Transportation of the Republic of Indonesia, 2015).

Acts against the law in international civil aviation have actually been regulated in several international conventions including: (1) Convention on Offenses and Certain Other Acts Committed on Board Aircraft (Tokyo Convention 1963); (2) Convention for the Suppression of Unlawful Seizure of Aircraft (1970 Hague Convention); (3) Convention for the Suppression of Unlawful Acts Against the Safety of Civil Aviation (Montreal Convention 1971); (4) Protocol for the Suppression of Unlawful Acts of Violence at Airports Serving International Civil Aviation, Supplementary to the Convention for the Suppression of Unlawful Acts Against the Safety of Civil Aviation (Montreal Protocol 1988); (5) Convention on the Marking of Plastic Explosive for the Purpose of Detection (Montreal Convention 1991); and most recently the Convention on the Suppression of Unlawful Acts relating to International Civil Aviation (Beijing Convention 2010) (see, Agrawala, 1973; Thomas \& Kirby, 1973; Fitzgerald, 1988).

The 2010 Beijing Convention was formed as a result of the 11 September 2001 tragedy in the United States. Unlawful acts in civil aviation that occurred on that day is a milestone in the conduct of new types of illegal acts (air piracy) in international civil aviation. In the September 11 attack, for the first time, the air hijackers did so with the intention of committing suicide and killing all the passengers and crew of the aircraft. In addition, air piracy in the September 11 tragedy was the first to use aircraft as "powerful weapons of mass destruction", where airplanes have become manned cruise missiles (Arasly, 2015) that are designed to destroy a certain vital object (a central government building or economic center). The 9/11 attack gave rise to the need to review and renew the various international conventions in order to anticipate new threats in the aviation world, which were then manifested in the form of the 2010 Beijing Convention.

As for in Indonesia, regulations regarding illegal acts in international civil aviation in various international conventions have been ratified and adopted into national law with various laws namely: (1) Law Number 2 of 1976 concerning Ratification of the 1963 Tokyo Convention, Convention The Hague 1970, and the 1971 Montreal Convention; (2) Law Number 4 of 1976 concerning Amendments and Additions to Several Articles in the Criminal Law Code Related to the Expansion of the Applicability of Criminal Legislation, Aviation Crimes, and Crimes Against Aviation Facilities/Infrastructure; and (3) Act Number 1 of 2009 concerning Aviation.

However, to date, Indonesia has not ratified the 2010 Beijing Convention, since signing it on September 10, 2010. On December 21, 2017, the Directorate General of Civil Aviation has received a State Letter from the Secretary General of ICAO Ref: LE 3/45 - 17/135 on Entry into Force of the Protocol Supplementary to the Convention on the Suppression of Unlawful Seizure of Aircraft, done at Beijing on September 10, 2010 (Doc 9959) which is an appeal to Indonesia to immediately ratify the 2010 Beijing Convention. As a member of ICAO (International Civil Aviation Organization/International Civil Aviation Organization), Indonesia has the responsibility and obligation to keep abreast of developments in international civil aviation arrangements and make it part of national law, which of course is adapted to national interests. Based on the background as described, the problem to be examined in this study is the urgency of the Ratification of the 2010 Beijing Convention on Enforcement of Unlawful Acts Related to International Civil Aviation. 


\section{Research Method}

The method used in this study is the Normative Juridical method, namely the research method "conducted by examining library material which is secondary data". This study combines three approaches namely the statutory approach, the conceptual approach and the historical approach. Data collection is carried out with literature and document studies, and is supported by interviews with competent sources. Secondary data obtained were then analyzed by qualitative methods, and then analyzed as thoroughly as possible and presented in the form of research reports..

\section{Unlawful Acts in International Civil Aviation and Its Conventions}

Acts against the law in international civil aviation are not new in the world of aviation, and even have been firmly regulated in various international air law instruments. The scope of unlawful acts in international civil aviation according to various international air law instruments is as follows:

1. Tokyo Convention 1963: "acts which, whether violating or not, may or may jeopardize the safety of the aircraft or the person or property in it or that endanger the order and discipline on the ship" (Article 1 Letter (b)

2. The 1970 Hague Convention: acts that "illegally, by force or threat, or by any other form of intimidation, seize or exercise control over the aircraft, or attempt to carry out such acts".

3. 1971 Montreal Convention: if a person unlawfully and intentionally performs a variety of actions both against a person and against an aircraft or flight navigation facility which causes the aircraft to be inoperable or appear to jeopardize flight safety. This convention also regulates the delivery of incorrect information which therefore endangers the safety of aircraft in flight.

4. The Montreal Protocol 1988, which is an addition to the provisions of Article 1 Paragraph (1) of the 1971 Montreal Convention, which is against unlawful and intentional unlawful acts both against people at an airport as well as acts of destruction or destruction of aircraft and facilities an airport that serves international civil flights.

5. Montreal Convention 1991: prohibition of making or transporting plastic explosives using aircraft.

The existence of various international air law instruments seems to have succeeded in reducing the occurrence of unlawful acts in international civil aviation. However, on September 11, 2001, a shocking event occurred to the world. The hijacking of four planes (American Airlines Flight 11, American Airlines Flight 77, United Airlines Flight 175, and United Airlines Flight 93) on that day was carried out by 19 members of the Al-Qaeda organization. Two of the four planes were crashed into the Twin Tower WTC (World Trade Center) in New York, one aircraft was crashed into the Pentagon (headquarters of the United States Department of Defense), and one more aircraft would be crashed into Washington, D.C. but failed and fell in Pennsylvania. Nearly 3,00o people were killed in the incident, including 227 passengers and 19 hijackers who were on the four planes. This event not only affected the United States in various fields, but also affected other countries throughout the world (Baum, 2016; Ghosh, 2002). The September 11 tragedy has clearly become one of the milestones in aviation security history, which makes everyone aware that air piracy, as a form of unlawful acts in international civil aviation, is a crime that has both domestic and international character, which is not only threatens human lives, but also threatens the sovereignty of a country (Idrees, 2016). Paul Stephen Dempsey (2003) in his article entitled "Aviation Security: The Role of Law in the War against Terrorism" even states that for some countries, aviation is a symbol of national aspirations of pride, prestige, and global penetration.

As a reaction to the September 11 tragedy, the 2010 Beijing Convention was adopted, which was an amendment and addition to the 1963 Tokyo Convention, the 1970 Hague Convention, and the 1971 Montreal Convention. The purpose of the formation of this convention was in response to the changes and developments of the times, especially those relating to the occurrence of criminal acts of 
terrorism in the form of air piracy in the international world. As can be seen from the September 11 Tragedy, aircraft and airports and flight navigation equipment were not the main targets of the attack, but the hijacked airplanes were instead used as a tool to attack buildings that were used as government centers and economic centers. Therefore, the 2010 Beijing Convention regulates among others the obligations of participating countries to criminalize a number of threats that can occur to the security of international civil aviation, the transportation of BCN (biological, chemical, and nuclear) weapons into aircraft, as well as arrangements regarding the use of aircraft civil flying as a weapon in acts of terrorism. In addition, it also regulates the liability of piracy actors, which not only includes individual pirates who are held accountable, but can also be imposed on organizations or countries that support air piracy crimes.

\section{The 2o1o Beijing Convention and Ratification Obligations}

As a member of ICAO, Indonesia has the responsibility and obligation to adopt various international air law provisions and rules, as well as various international rules regarding acts against the law in international civil aviation. This has been done, inter alia, by enacting Law Number 2 of 1976 concerning Ratification of the 1963 Tokyo Convention, the 1970 Hague Convention, and the 1971 Montreal Convention; and enacting Law Number 4 of 1976 concerning Amendments and Additions to Several Articles in the Criminal Law Code Related to the Expansion of the Applicability of Criminal Legislation, Aviation Crimes, and Crimes Against Aviation Facilities/Infrastructure. Both of these laws were established on the basis of the awareness that at that time there were no criminal law provisions in force in Indonesian aircraft, against aviation crimes or crimes against aviation facilities/infrastructure. It is also based on the desire to provide guarantees of safety and security as well as protection for passengers, flight crew, goods that are in flight as well as for flight facilities/infrastructure in case of aircraft mastery against the law as well as various acts that interfere with flight security and facilities/aviation infrastructure.

On the other hand, since joining the Beijing Convention 2010 on September 10, 2010, Indonesia has not ratified the convention. Even though as a member of ICAO, Indonesia is obliged to follow the development of international civil aviation arrangements and make it part of national law, specifically related to the state as an authorized and responsible party to provide legal protection, both preventive and repressive, for all nations, and to enforce the law in all of Indonesia's blood spill as an embodiment of Indonesia as a rule of law. This is also in line with the opinion of Damos Dumoli Agusman (Interview conducted on June 22, 2018) who said that "Indonesia needs to ratify the 2010 Beijing Convention because Indonesia has an interest in maintaining and improving flight security at the national and international level". It was further said that some of the provisions of amendments/additions that existed in the 2010 Beijing Convention were considered quite significant with the changing times and in line with Indonesia's interests, including the prohibition of carrying or using BCN weapons, explosives, radioactive materials, or similar in or against an aircraft that can cause death, injury or serious damage to property or the environment; (2) the addition of criminal offenses in the form of cyber attacks on flight navigation facilities that can threaten flight safety; (3) expansion of jurisdiction with the entry into force of the convention on civil aviation both international and domestic where the place of takeoff or landing as well as the occurrence of violations are outside the territory of the aircraft's nationality country; and (4) the obligations of each participating country in the convention to carry out criminal proceedings if violations occur within its territory, are the nationality of the aircraft, or are the nationality or residence of the offender, and/or are the victim's nationality. Therefore, the ratification of the Beijing Convention 2010 needs to be immediately carried out by the Government of Indonesia.

\section{Conclusion}

The development and changes that occur in the world of international civil aviation are inevitable, 
given the rapid advancement of technology in aviation. This is also the case with increasingly widespread unlawful acts in international civil aviation. International arrangements regarding acts against the law in international civil aviation will not be effectively implemented, if not ratified and ratified into national law, of course, after adjusting to national interests. For that reason, as an ICAO member state, as well as in the context of providing legal protection, both preventive and repressive, for all Indonesians, as well as to enforce laws throughout Indonesia as a manifestation of Indonesia as a state of law, it is very urgent to immediately ratify the 2010 Beijing Convention.

\section{Reference}

Abeyratne, R. (2018). State Responsibility for Exogenous Interference with Air Navigation: Some Legal and Regulatory Issues. Air and Space Law, 43(1), 61-75.

Abeyratne, R. (2019). Interference with Air Navigation. In Legal Priorities in Air Transport (pp. 123-136). Springer, Cham.

Agrawala, S. K. (1973). Aircraft Hijacking and International Law. Journal of Air Law and Commerce, 39(4), 659.

Arasly, J. (2005). Terrorism and Civil Aviation Security: Problems and Trends. Connections, 4(1), 75-90.

Baum, P. (2016). Violence in the skies: a history of aircraft hijacking and bombing. Summersdale Publishers LTD.

Chareonwongsak, K. (2002). Globalization and technology: how will they change society?. Technology in Society, 24(3), 191-206.

Dempsey, P. S. (2002). Aviation security: the role of law in the war against terrorism. Colum. J. Transnat'l L., 41, 649.

Dwidjowijoto R.N., \& Sumampouw, M.P. (1997). Globalisasi, Ancaman Atau Peluang, In Dwidjowijoto R.N., \& Sumampouw, M.P (Eds), Manajemen Dalam Era Globalisasi. Jakarta: PT Elex Media Komputindo

FitzGerald, G. F. (1974). Recent proposals for concerted action against states in respect of unlawful interference with international civil aviation. J. Air L. E Com., 40, 161.

Fitzgerald, G. F. (1988). Aviation Terrorism and the International Civil Aviation Organization. Canadian Yearbook of International Law/Annuaire canadien de droit international, 25, 219-241.

Ghosh, C.N. (2002). Analysis of the Hijackings on September 11, 2001, Suggested Measures for Prevention. Indian Defence Review 17(2), 52-63. Retrieved from https://www.satp.org/satporgtp/publication/idr/vol_17(2)/CN_ghosh.htm

Idrees, B. M. H. (2016). Critically Analyse: The Laws Relating to Hijacking. Available at SSRN 2746397.

Quebral, N. C. (2006). Development communication in a borderless world. Glocal Times, (3).

Sitabuana, T.H. (2001). Technical Assistance Agreement as a Means of Technology Transfer in Indonesia. (Thesis, Master of Law Program at Diponegoro University).

The Ministry of Transportation of the Republic of Indonesia. (2015). The Ministry of Transportation Issues PM No. 140 of 2015 concerning the National Aviation Security Emergency Management Program. Jakarta: The Ministry of Transportation of the Republic of Indonesia. Retrieved 11 February 2019 from http://hubud.dephub.go.id/?id/news/detail/2691.

Thomas, C. S., \& Kirby, M. J. (1973). The Convention for the suppression of unlawful acts against the safety of civil aviation. International \& Comparative Law Quarterly, 22(1), 163-172. 